DOI 10.15826/qr.2017.2.237

УДК 94(100)"1939/45"+94(430)"1939/45"+930.24

8-9 МАЯ 1945 ГОДА И ДЛИННЫЕ ТЕНИ ВОЙНЫ

Хартмут Рюсс

Вестфальский университет имени Вильгельма,

Мюнстер, Германия

\title{
8/9 MAY 1945 AND THE LONG SHADOWS OF WAR
}

\author{
Hartmut Rüß \\ Westfälische Wilhelms-Universität, \\ Münster, Germany
}

On the basis of personal memoirs and family histories, the author reproduces the situation in Germany at the end of the Second World War. He concentrates his attention on the material position and spiritual state of normal Germans, for whom the total defeat of their country meant famine, expulsion, destruction, and moral depression. Reflecting on the fact that the majority of Germans (in distinction from the other peoples of Europe) did not consider the collapse of the Nazi regime as liberation, the author discusses differences in perception of VE Day in the German Democratic Republic and the German Federal Republic. He places especial significance on the speech of Federal President Richard von Weizsäcker for the formulation of a new approach to evaluating the results of the Second World War for Germany. His 1985 address on the subject of the years after the conclusion of the war, an explicit censorship of the West German interpretation of the 1945 capitulation, was the first to attribute a positive meaning to these events for all Germans and called for the establishment of friendly contacts with the Soviet Union. The concluding remarks relate to the problem of national historical memory, its connection with forms of commemoration (such as the celebration of Victory Day), and the need to take a scholarly approach when studying the Second World War.

Keywords: Second World War; the defeat of Germany; historical memory; Richard von Weizsäcker.

* Citation: Rüß, H. (2017). 8/9 May 1945 and the Long Shadows of War. In Quaestio Rossica, Vol. 5, № 2, p. 537-551. DOI 10.15826/qr.2017.2.237.

Цитирование: R̈̈ß H. 8/9 May 1945 and the Long Shadows of War // Quaestio Rossica. Vol. 5. 2017. № 2. P. 537-551. DOI 10.15826/qr.2017.2.237 / Рюcс X. 8-9 мая 1945 года и длинные тени войны // Quaestio Rossica. T. 5. 2017. № 2. C. 537-551. DOI 10.15826/qr.2017.2.237.

(C) Рюсc X., 2017

Quaestio Rossica • Vol. 5 • 2017 • № 2, p. 537-551 
На основе личных воспоминаний и семейной истории автор воспроизводит ситуацию в Германии, сложившуюся к концу Второй Мировой войны. Его внимание сосредоточено на материальном положении и духовном состоянии простых немцев, для которых тотальное поражение их страны обернулось голодом, изгнанием, разрушениями и моральной депрессией. Размышляя о том, почему большинство немцев, в отличие от других народов Европы, не воспринимали крах гитлеровского режима как освобождение, автор отмечает различия восприятия событий 8-9 мая в ГДР и ФРГ, придавая особенное значение речи федерального президента Рихарда фон Вайцзеккера в формировании нового подхода в оценке итогов Второй мировой войны для Германии. Его выступление по поводу 40-й годовщины окончания войны в 1985 г., которое можно считать явной цензурой западногерманской интерпретации дня капитуляции 1945 г., впервые приписывало этому событию положительный смысл для всех немцев и призывало к установлению дружественных контактов с Советским Союзом. Заключительные размышления касаются проблем национальной исторической памяти и связанных с этим форм коммеморации - празднования Дня Победы и необходимости следования научному подходу в изучении Великой Отечественной войны.

Ключевые слова: Вторая мировая война; поражение Германии; историческая память; речь Рихарда фон Вайцзеккера.

Моя жена Фрейя и я, родившиеся в 1941 г., дети войны. Мы, таким образом, принадлежим к так называемому «забытому поколению», о котором пишет Сабина Боде в своем бестселлере, впервые опубликованном в 2004 г. [Bode]. Ничто другое так отчетливо не проясняет актуальность проблемы «длинных теней войны», как эта книга, которая к 2014 г. выдержала уже двадцатое издание. Боде приводит исследования, в результате которых выясняется: от 8 до 10 \% тех, кому сегодня по 70-80 лет и кто детьми и подростками пережили войну и изгнание, до сих пор страдают от посттравматического расстройства, и еще 25 \%, несмотря на менее существенные последствия, испытывают постоянные серьезные проблемы в «социально-психологической области жизни» [Ibid., S. 12].

Мое самое раннее воспоминание вообще связано с первыми майскими днями 1945 г. Это воспоминание чрезвычайно двойственно. Я вижу себя на руках какого-то советского солдата, который меня ласково похлопывает и шутливо поддразнивает, глядя на меня сияющими глазами. Во всяком случае, я, кажется, почувствовал беспредельное облегчение, когда заглянул в глаза «доброго», а не «злого волка». Это, заметьте, самое первое воспоминание в моей жизни [Rüß, 2013]!

В конце января 1945 г. мать моей жены вместе с четырьмя маленькими детьми возрастом от семи месяцев до четырех лет, своей 13-летней сестрой и свекровью пустилась в бегство из Позена на запад с обозом из 20 конных повозок. Стоял сильный мороз. На окраине города польские женщины раздавали горячее молоко для маленьких детей. Моя теща всегда с благодарностью вспоминала об этом проявлении 
человечности. Из-за непредвиденной и, как выяснилось впоследствии, счастливой случайности их упряжка сбилась с пути, в то время как главный обоз оказался под обстрелом со стороны русских. Но даже без непосредственного соприкосновения с противником положение беженцев было драматичным, как позже вспоминала тетка моей жены:

21 января - яркий солнечный день, но очень холодно... В кюветах лежат опрокинутые повозки беженцев и несколько мертвых лошадей. На краю дороги в снегу на коленях стоят женщины, со страшными криками и рыданиями поднимая своих детей к небу и прося взять их с собой... Страшное утро! Люди, отчаянно молящие о помощи, и ты ничего не можешь для них сделать. Очень медленно мы тащимся мимо них дальше [Einige Familiengeschichten, S. 88].

Через Берлин, который бабушка хотела «защищать на баррикадах», семья в феврале оказалась в Лейпциге, который в то время бомбили американцы. Отец, к этому времени служивший в Главном ведомстве государственной безопасности рейха (РСХА) в Берлине и одновременно бывший начальником эсэсовской команды сопровождения генерала Власова, устроил дальнейшую транспортировку семьи совместно с русскими эмигрантами и людьми Власова в тогда еще мирный Карлсбад на территории современной Чехии, и оттуда - в Баварию. Будучи бывшим членом оперативной группы СС, после войны он скрывался, работая лесорубом, пока в 1954 г. не погиб при так и не выясненных обстоятельствах в мотоциклетной аварии. Дети помнят его как скрытного, замкнутого в себе и недоступного для них человека, которого мучили кошмары, не отпускавшие его из прошлого, что делало его, несмотря на совместное проживание, невероятно далеким от них.

Мой отец по причине его деятельности в качестве бывшего руководителя местной организации НСДАП и руководителя окружного отделения Национал-социалистического союза учителей в августе 1945 г. был арестован и на три года исчез из нашего поля зрения. Он сидел без права переписки в специальном лагере НКВД № 9 Фюнфайхен под Нойбранденбургом [Mironenko, Niethammer, von Plato]. Вплоть до смерти в 1968 г. он молчал о своем лагерном заключении. Но и о своих переживаниях в России, где он служил старшим казначеем в группе армий «Юг», он с нами не говорил, а мы и не спрашивали. Во многих семьях тогда существовали такие коммуникационные барьеры между поколениями, если речь заходила о недавней истории и войне на Востоке [Heer, Naumann]. В таких взаимоотношениях между родителями и детьми также отчетливо проявлялись «длинные тени войны».

Сестра моей матери, 3 мая 1945 г. направлявшаяся в повозке моего дедушки в западную оккупационную зону, попала в местечке Бливенсторф (округ Пархим) под перекрестный огонь, когда некий фанатично настроенный офицер СС начал арьергардный бой при отступлении. Он с заряженным пистолетом помешал нескольким ре- 
шительным жителям вывесить белые флаги на церковной колокольне. Она погибла на месте на глазах своих трех маленьких детей: пуля попала ей прямо в сердце! Так же погиб и поляк - кучер ее повозки [Redmer]. В 2011 г. я вместе с моим двоюродным братом, который, как это ни странно, попал туда впервые, побывал на месте этой нелепой и бессмысленной трагедии. Он ничего не помнит, свою мать он знает лишь по фотографиям. Мне казалось, что ныне мирно лежащая перед нами деревня была для него забытым или вытесненным из памяти местом утраты его первичного глубинного доверия к миру. Он стоял и под натиском наплывших картин и эмоций лепетал какие-то беспомощные слова, которые вскоре утонули в молчании. Третье мая 1945 г. после многолетних попыток подавить воспоминания нахлынуло с новой силой. Я не задавал вопросов и оставил его в покое ${ }^{1}$.

Эти события, произошедшие в моем самом близком семейном кругу - лишь малая часть общего для всей Германии гибельного сценария 1945 г., который закончился двойной капитуляцией в Реймсе и Берлине - Карлсхорсте 8 и 9 мая и означал конец нацистского господства ${ }^{2}$. Так называемый «тысячелетний рейх» лежал в руинах, в стране свирепствовали голод, нужда, нищета, страх и отчаяние. Многие испытали насилие или погибли - на фронте, в концентрационных лагерях, под массированными бомбежками городов, в качестве беженцев. 4,2 млн солдат всех частей вермахта погибли на полях сражений Европы и Африки, 2 млн попали в плен. 600 тыс. гражданских лиц стали жертвами бомбежек западных союзников, 13 млн человек оказались без крова и искали прибежища в сельской местности. Бездомность стала массовым явлением, инфраструктура была разрушена, многие памятники архитектуры и культуры лежали в руинах и пепле. В 1946 г. в четырех зонах оккупации насчитывалось почти 10 млн изгнанных. В конце 1945 г. в Кёльне только 12 \% детей имели соответствующий их возрасту нормальный вес. Средний вес взрослых мужчин в американской зоне оккупации в середине 1946 г. составлял всего 51 кг [Kocka, 1994, S. 163, 164; Jacobsen, S. 4]. Если до войны немцы по фактору обеспеченности населения продуктами питания занимали одно из первых мест в Европе, то осенью 1945 г. они оказались голодранцами № 1 . Объемы производства на душу населения в конце 1946 г. упали до уровня 1865 г. (!). Промышленное производство в сентябре 1945 г. в британской зоне оккупации сократилось до 14,6 \%, а в американской до $10 \%$ от довоенного уровня. Воровство угля и продуктов питания,

\footnotetext{
${ }^{1}$ После воссоединения Германии в деревне были установлены 20 черных камней в память о погибших там немецких солдатах, опознанных лишь частично. Павшим восьми красноармейцам и убитым гражданским лицам никаких памятных знаков нет.

${ }^{2}$ Как известно, документ о безоговорочной капитуляции германского вермахта был подписан дважды и в двух разных местах: 7 мая в Реймсе в Верховном штабе союзных экспедиционных сил в Северо-Западной Европе (Supreme Headquarters Allied Expeditionary Force) - он вступил в силу 8 мая в 23 ч 01 мин. по среднеевропейскому времени (MEZ), и 9 мая в 00 ч 16 мин. по среднеевропейскому времени в Берлине Карлсхорсте в ставке советской 5-й армии, где подписями главнокомандующих всех родов войск вермахта был ратифицирован акт о безоговорочной капитуляции.
} 
черный рынок, мешочничество, проституция, вызванная бедностью, и всеобщие депрессивные настроения были внешними знаками нараставшей деградации [Trittel, S. 20, 28]. Казалось, подтверждалось то, что Гитлер предсказывал немецкому народу в речи в берлинском дворце спорта 16 декабря 1940 г.: если в «своей национальной сплоченности» он не сможет осуществить свои «жизненные притязания», «тогда этот народ пропадет, тогда он будет отброшен назад, и тогда не будет смысла жить в этом народе!» (цит. по: [Kocka, 1994, S. 162f]).

Чтобы избежать недоразумений: здесь не идет речи о том, чтобы считаться количеством смертей, разрушений и страданий людей. Это не подобает немцам. В конечном итоге именно Гитлер начал войну. Причем война эта не носила оборонительного характера со стороны Германии и так называемого «Абендланда» против западной «плутократии» и советского «мирового большевизма», как это пыталась внушить нацистская пропаганда, чтобы скрыть свои безумные цели от собственного народа. Поэтому катастрофический конец для немцев в 1945 г. непредставим без связи с захватом власти Гитлером в 1933 г. На примере германской истории со времени образования Второго рейха в 1871 г. можно ясно понять, как так называемый «здоровый патриотизм» ${ }^{3}$ может перерасти в национализм, шовинизм и преступную бесчеловечность, если наличествуют соответствующие политические и социальные условия, которые этому способствуют. Хорошо известно мрачное предсказание австрийского поэта Франца Грильпарцера (1791-1872), согласно которому путь от гуманизма через национализм ведет к зверству, что подтверждается тем моральным опустошением, которое в умах многих немцев было вызвано нацистским режимом.

Итак, мы можем констатировать: элементарное выживание для большинства немцев в 1945 г. было в центре их мыслей и действий. Поражение было тотальным, будущее - неопределенным. Вопросы так называемой большой политики интересовали очень немногих. Апатия и разочарованность, скорбь о погибших и утраченной родине, безнадежность и отсутствие перспектив, страх перед местью победителей, а также перед сексуальным насилием, сильно выраженная жалость к себе составляли основные настроения широких слоев населения [Echternkamp, S. 34-40; Gebhardt; Trittel]. «Немецкий народ - такая запоминающаяся, а также

3 Социально-психологические исследования наводят на мысль, что различение между «хорошим» патриотизмом и достойными критики национализмом и шовинизмом не имеет никаких оснований в реальности. По Кристоферу Корсу, «люди с патриотическими настроениями не отклоняют национализма, скорее и то, и другое часто идут рука об руку». Патриотические настроения способствуют формированию враждебного к чужакам расистского образа мыслей (op. cit.: [Westerhoft]). «Ура-патриотизм» - уничижительное определение одной из форм патриотизма, которая сопутствует военной эйфории («Ура, гордая прекрасная женщина, ура, Германия... как бодро вынешь ты свой меч... для защиты своего очага...» - Фердинанд Фрайлиграт, 1870 г.). До мартовской революции 1848 г. патриотизм в Германии прежде всего был отмечен стремлением к национальному единству на землях Германского союза, после 1871 г. он имел тенденцию к перерастанию скорее в форму национального зазнайства («Am deutschen Wesen soll die Welt genesen» - «По немецкому нраву должен оздоровиться мир» [Kronenberg]). 
многократно встречающаяся картина первого послевоенного времени объединенный в невзгодах и лишениях» [Herbert, S. 551].

Но не только это: масштаб вины, которой были отягощены немцы за систематическое уничтожение евреев и других считавшихся расово неполноценными групп населения (внеобщественных элементов, цыган, умственно и физически неполноценных, гомосексуалистов), был непостижим и непереносим. Многие испытывали потаенный стыд из-за того, что верили лживой пропаганде нацистов и следовали преступной политике режима и великодержавным химерам Гитлера. Это нашло отчетливое выражение в «Штутгартском признании вины евангелической церкви» от 19 октября 1945 г.:

С невыразимой болью мы говорим: через нас многим народам и странам были принесены бесконечные страдания. Мы обвиняем себя за то, что признавались в этом недостаточно мужественно [Glaser, S. 14].

Уже 23 августа 1945 г. католические епископы в Фульде опубликовали пастырское послание, в котором среди прочего значилось:

Многие немцы, в том числе и из наших рядов, позволили обмануть себя фальшивым учением национал-социализма и оставались безучастными к преступлениям против человеческой свободы и человеческого достоинства; многие своим поведением оказывали содействие преступникам, многие сами стали преступниками [Kleßmann, S. 377].

Однако широкие слои населения ничего не хотели знать об ответственности за войну или даже о «коллективной вине» ${ }^{4}$. Посыпались протесты. Многие не могли или не хотели смириться с мыслью о прожитой на протяжении 12 лет «фальшивой» жизни, а теперь принять требование о признании хотя бы косвенной общей ответственности за злодеяния национал-социалистического времени. Согласно опросу, проведенному американскими оккупационными властями, еще в конце 1947 г. более 50 \% респондентов оценивали национал-социализм как в принципе хорошую, но плохо реализованную идею [Merrit A., Merrit R., S. 33, 295]. Подобная внутренняя установка вкупе со взглядом на мрачное настоящее сама по себе не позволяла позитивного толкования капитуляции.

Разумеется, нельзя обойти вниманием то, что значительная часть населения воспринимала конец нацистского господства и безоговорочную капитуляцию как весьма страстно желаемое освобождение. К ней принадлежали в первую очередь все те, кто были жертвами национал-социалистского преследования по политическим, расовым, религиозным и другим причинам и пережили заключение в тюрьмах и концентрационных лагерях. Далее к ним относились те, кто бежали

\footnotetext{
${ }^{4}$ Примыкавший к оппозиции Гитлеру мюнстерский епископ фон Гален в проповеди 1 июля 1945 г. резко отрицал «коллективную вину» всех немцев [Bischof August Graf von Galen, S. 1174f].
} 
от нацистов за границу и возвращались теперь как реэмигранты. Они неоднократно становились объектами критики и вражды за то, что наблюдали за гибелью родины из якобы «удобной ложи эмиграции» (см.: [Rückkehr und Aufbau; Krauss]) ${ }^{5}$. К освобожденным относились, наконец, находившиеся на немецкой земле военнопленные и принудительно угнанные на работы. Известно, что в пресловутом приказе № 270 те красноармейцы, которые попали в плен, были заклеймены Сталиным как предатели. Для многих из возвратившихся тернистый путь не заканчивался, и они попадали из огня да в полымя 6 .

В связи с противоречивым восприятием и оценками дня 8 мая в первое послевоенное время в Германии мне хотелось бы еще раз обратиться к своему субъективному опыту. В то время моя 28-летняя родственница, которая отбывала трудовую повинность в качестве учительницы в музыкальной школе в Дойч-Эйлау (совр. польск. Илава), описала владевшие ею во время бегства вместе с матерью на Запад чувства таким образом:

Никогда в жизни я не чувствовала себя такой свободной, такой богатой, как тогда, пробираясь пешком через леса Западной Пруссии под ясным звездным небом морозной ночи без определенной цели, без отягощающего багажа [Einige Familiengeschichten, S. 88] .

Подобные эйфорические настроения в среде молодых людей, у которых будущее еще было впереди и которые не были так отягощены прошлым, как старшее поколение, очевидно, встречались чаще, чем можно было бы предположить при взгляде на поверженную Германию ${ }^{7}$. Во всяком случае, такие прагматично ориентированные молодые люди и массы населения после «немецкой катастрофы» (Ф. Майнеке) направили все свое внимание и всю энергию на разбор завалов и улучшение своих условий жизни. Так называемое «экономическое чудо» в молодой феде-

\footnotetext{
${ }^{5}$ Прежде всего социал-демократические политики (В. Хегнер, Э. Олленхауэр, Э. Рейтер, Г. Венер, В. Брандт) после 1945 г. вернулись и сделали политическую карьеру в Западной Германии. В советской зоне оккупации вернувшаяся из Москвы группа во главе с В. Ульбрихтом при поддержке советской военной администрации заняла доминирующее положение на восточногерманской политической сцене, несмотря на изоляцию от широких слоев населения. Коммунисты пользовались некоторым авторитетом как борцы сопротивления против Гитлера и благодаря своим тесным связям с Советами могли распределять посты, что способствовало росту их числа [Weber, 1978, S. 24-31].

${ }^{6}$ Нахождение в плену расценивалось как позорное пятно, и те, кому это довелось пережить, пытались скрывать это обстоятельство как можно тщательнее. Большая часть репатриированных пленных была амнистирована после ХХ съезда КПСС в 1956 г. До конца 1980-х гг. публичная дискуссия по поводу судьбы побывавших в плену красноармейцев в Советском Союзе расценивалась как запретная тема [Streit, S. 23, 295].

Гельмут Шельтский в 1957 г. характеризировал послевоенную молодежь, которую он называл «скептическим поколением», как «здравомыслящую, свободную от идеологии и способную сопротивляться пропаганде» [Schelsky, S. 74ff]. К ней я причисляю также моего брата, который в 1946 г. в возрасте 16 лет покинул семью и ночью бежал через «зеленую границу» из советской зоны, где он не видел для себя никакого будущего, на Запад. Там после получения гимназического и университетского образования он сделал карьеру в области экономики.
} 
ративной республике 1950-х гг. едва ли объяснимо без такой прямо-таки маниакальной концентрации на достижении хотя бы более или менее скромного благосостояния. Исключительность этого стремления была одновременно связана с сильной энергией вытеснения негативного прошлого из памяти, и, пожалуй, даже только благодаря ей оно было осуществимо. Уже в 1946 г. К. Ясперс писал о немцах в конце войны: «Ничего не хочется слушать о вине, о прошлом... хочется просто прекратить страдать, выбраться из нищеты, хочется жить, но не задумываться. Это скорее настроение, когда после таких ужасных страданий... более требуется утешение, чем обременение обвинениями» [Jaspers, S. 7f.]. В этом, по-моему, лежит очень важный ключ к пониманию того факта, что большинство не воспринимало окончание войны как освобождение или даже, возможно, было не способно так его воспринимать. Поскольку прошлое Третьего рейха вытеснялось из памяти, одновременно исчезало и восприятие победы союзников над нацистской Германией как «акт освобождения». Начальник информационного отделения советской военной администрации в Германии полковник Сергей Тюльпанов, пожалуй, исходил из того, что «освобождение» - это слово из политическо$2 о$ лексикона, которое, однако, совершенно не затрагивало жизненных чувств большинства немцев в 1945 г. (op. cit.: [Jäger M., S. 34]).

Объявление западными союзниками 8 мая днем победы в Европе (VE-day), а Советским Союзом 9 мая - Днем Победы было оправданным выражением триумфа над ненавистной нацистской Германией. Если в ГДР к 30-летнему (1975) и 40-летнему (1985) юбилеям окончания войны День Победы праздновался и был объявлен нерабочим днем, то это можно было понять только как политический реверанс советскому «большому брату». Историческое обоснование этого было возможно только путем игнорирования общегерманской реальности 1945 г. С 1950 г. и до введения пятидневной рабочей недели в 1967 г. официальным праздничным днем в ГДР было 8 мая как «день освобождения немецкого народа от гитлеровского фашизма» ${ }^{8}$.

В Федеративной республике Германии официальным лицам с самого начала по уже изложенным причинам память о капитуляции давалась с трудом. Правда, в течение следующих 40 лет со стороны высоких представителей государства периодически звучали публичные высказывания о национал-социалистском прошлом и капитуляции. Так, первый президент ФРГ Теодор Хейс в 1949 г. формировал общественное мнение словами о «немецком коллективном стыде». А третий президент, социал-демократ Густав Хайнеман, соавтор процитированного выше Штутгартского заявления о вине, перед избранием в должность на вопрос об отношении к патриотизму дал часто цитируемый ответ: «Да что вы, я не люблю государство, я люблю свою жену!» А в 1970 г. он первым из выдающихся политиков произнес речь в память о 8 мая (op. cit.: [Jäger W.]).

\footnotetext{
${ }^{8}$ В воссоединенной Германии 8 мая не считается праздничным днем, хотя в этот день проводятся многочисленные мероприятия, так, в 2005 г. в Берлине день памяти об окончании войны был проведен как «день демократии».
} 
Но действительно широкий международный резонанс имела речь президента Рихарда фон Вайцзеккера перед бундестагом, произнесенная в 1985 г. по поводу 40-й годовщины окончания войны. В ней он обозначил 8 мая как «день освобождения от презирающей человека системы национал-социалистской тирании» и среди прочего заявил:

Сегодня многие народы помнят день, когда завершилась Вторая мировая война в Европе... 8 мая 1945 г. - дата решающего значения... Мы, немцы, отмечаем этот день, и это необходимо. Мы сами должны определить масштабы... 8 мая - это для нас прежде всего день воспоминания о том, что люди должны были претерпеть... У нас нет причин в сегодняшний день участвовать в празднованиях победы. Но мы имеем все основания осознать 8 мая 1945 г. как конец ложного пути немецкой истории... Сегодня мы со скорбью вспоминаем обо всех жертвах войны и тирании... Мы помним обо всех народах, которые страдали на войне, прежде всего о несказанно многих гражданах Советского Союза и Польши, которые лишились жизни. Как немцы мы помним в скорби о своих соотечественниках, которые погибли как солдаты при налетах авиации на родине, в плену и при изгнании. $<\ldots>$. Абсолютное большинство нашего сегодняшнего населения в те времена было либо в младенчестве, либо еще не родились. Они не могут признавать собственную вину за то, чего они вовсе не совершали... Но предки оставили им тяжелое наследство... Речь не идет о том, чтобы преодолеть прошлое. Это невозможно... Но тот, кто закрывает глаза на прошлое, становится слепым для настоящего. Тот, кто не хочет вспоминать о бесчеловечности, становится восприимчивым к опасности нового заражения [Вайцзеккер, с. 1].

Вайцзеккер был первым федеральным президентом, который использовал годовщину капитуляции как повод, чтобы придать событию 8 мая 1945 г. положительный смысл для всех немцев9. То, что из его уст прозвучало слово «освобождение», повышало не только его личный престиж, но и авторитет его Христианско-демократической партии, до тех пор категорически уклонявшейся от подобной интерпретации с оглядкой на ее правоконсервативный электорат, из рядов которого и теперь еще раздавалась резкая критика. Тем не менее, факт новой оценки событий 8-9 мая в середине 1980 -х гг. явственно витал в воздухе. Важное объяснение тому дал сам федеральный президент, когда указывал на то, что преобладающая часть современного населения Германии принадлежала к тому поколению, которое родилось после войны, а значит, не было отягощено личными переживаниями.

\footnotetext{
${ }^{9}$ Уже за 17 дней до того во время церемонии возложения венков в бывшем концлагере Берген-Бельзен тогдашний федеральный канцлер Г. Коль также заявил: «Крах национал-социалистической диктатуры 8 мая 1945 г. был для немцев днем освобождения». Правда, в отличие от Вайцзеккера, он адресовал это заявление только к «свободной части нашего отечества». К тому же на речь Коля легла тень из-за того, что его запланированный с американским президентом Рейганом совместный визит на военное мемориальное кладбище в Битбурге, задуманный как жест примирения, столкнулся с международной ожесточенной критикой из-за того, что там, кроме прочих, были захоронены также бывшие военнослужащие СС.
} 
То, в какой мере избрание 11 марта 1985 г. Генеральным секретарем КПСС М. Горбачева, провозгласившего курс на решительные реформы и еще при Ю. Андропове накопившего опыт заграничной работы на Западе, оказало влияние на точку зрения немецких политиков, требует дополнительного тщательного анализа с привлечением источников. В любом случае изменившееся соотношение сил в Москве было благосклонно принято к сведению в Западной Германии. С этим обстоятельством были связаны позитивные ожидания, которые президент Р. Вайцзеккер упомянул в своей речи:

Генеральный секретарь Коммунистической партии Советского Союза Михаил Горбачев объявил, что советское руководство в связи с 40-й годовщиной окончания войны не намеревается разжигать антинемецкие настроения. Советский Союз, по его словам, выступает за дружбу между народами. Именно сейчас, когда у нас есть множество открытых вопросов по вкладу Советского Союза в развитие взаимоотношений между Востоком и Западом, а также по вопросам соблюдения прав человека... мы не должны допустить, чтобы этот знак из Москвы прошел мимо нас. Мы хотим дружбы с народами Советского Союза [[Вайцзеккер, с. 12].

В любом случае новые, положительные благодаря политике перестройки и гласности представления о Советском Союзе вполне могли повлиять и на культуру воспоминания, существовавшую в Западной Германии по вопросу 8 мая 1945 г. Однако важнейшей причиной для изменения взгляда на 8 мая 1945 г., с моей точки зрения, была следующая: ФРГ, если оглянуться на ее историю вплоть до самого начала, оказалась успешной моделью и в политическом, и в экономическом отношении. Из послевоенных руин выросли хорошо функционирующее государство и эффективная рыночная экономическая система, которые способствовали относительно высокому общественному благосостоянию. Без нового начала с «часа ноль» - это стало понятно при взгляде на прошедшие 40 лет - такое развитие было бы немыслимым. Германия, правда, в политическом отношении опустилась до статуса второстепенной державы. Это была плата за огромный скачок в демократической и экономической областях по сравнению с Веймарской Республикой. Традиционные общественные обременения и напряженности, которые способствовали ее ослаблению, перестали действовать из-за национал-социалистического «народного единства» (Volksgemeinschaft $)^{10}$, войны и ее исхода: социальный класс заэльбских крупных аграриев как носителей идеи авторитарного государства исчез, милитаристские традиции были дискредитированы, бывшее сопротивление модернизации и либерализации было существенно ослаблено, демократическая конституция и демократическое будущее больше не ставились под сомнение, как это было в 19181919 гг. [Kocka, 1980, S.13]. Таким образом, временная дистанция

10 «Народное государство Гитлера» - название одной из важнейших научных работ о национал-социализме последних лет (см.: [Götz]). 
в 40 лет позволила в середине 1980-х гг. придать 8 мая 1945 г. положительную оценку, резко отличавшуюся от той, которой придерживалось большинство немцев в середине 1940-х гг. Теперь стало возможным принять безоговорочную капитуляцию как освобождение, явившееся стартовой площадкой для лучшего будущего.

Но вместе с тем многие отрицательные последствия поражения все еще существовали. Требование единства и свободного самоопределения для всего немецкого народа, установленное в преамбуле Конституции ФРГ от 8 мая 1949 г., не было осуществлено и в 1985 г. (многие же, якобы трезво оценивая политическую ситуацию, вовсе не считали его возможным). Важные процессы и политические обстоятельства, которые проявились после окончания войны как следствия противоречий между Востоком и Западом ${ }^{11}$, - продолжающийся раскол Германии, отсутствие свободного самоопределения восточногерманского населения из-за однопартийной диктатуры СЕПГ, утрата родины из-за бегства и изгнания - как раз-таки не были совместимы с понятием освобождения. Тем не менее, слова Вайцзеккера свидетельствовали в конечном счете и о том, как фундаментально изменилась немецкая культура воспоминания об окончании войны.

Направленная на укрепление идентичности инсценировка «Дня Победы» в Советском Союзе и России с трофейными знаменами, военными парадами и цветами, несомненно, имеет свои исторические и моральные основания. Тем не менее, становится достойным критики, если при этом сознательно выносятся за скобки и замалчиваются негативные страницы собственного военного прошлого, что на протяжении долгих лет имело место в советской историографии, где приукрашивание Великой Отечественной войны, весьма далекое от опыта отдельно взятого человека, наблюдалось сплошь и рядом. В результате у многих, как, например, у писателя Виктора Астафьева, складывалось впечатление, что они участвовали в совершенно другой войне. Короткая фаза более открытого обращения к сталинскому прошлому после XX съезда КПСС пролила свет на репрессии в отношении военных и их негативные последствия. Появились более реалистичные данные об общих потерях, были опубликованы пресловутые сталинские приказы № 270 от 16 августа 1941 г., в котором военный плен был приравнен к предательству, и № 277 от 28 июля 1942 г., согласно которому создавались штрафные батальоны и заградительные отряды за линией фронта [Bonwetsch] ${ }^{12}$. С конца 1980-х

11 Созданная по необходимости, антигитлеровская коалиция позволила только на время отодвинуть идеологические и политические противоречия между Советским Союзом и англосаксонскими демократиями. Уже 9 февраля 1946 г. Сталин в своей речи подчеркнул, что столкновение социалистического и капиталистического миров рано или поздно должно быть неизбежным [Fischer, S. 14]. На Западе распространялись представления о том, что «мир стоит перед смертельной угрозой миру и свободе», источником которой считался «коммунистический тоталитаризм в образе Советской империи» [Geyer, S. 369ff].

1213 марта 1946 г. Сталин озвучил данные о 7 млн советских жертв войны. Комиссия министерства обороны установила другую цифру - 27-28 млн погибших, из них 8,7 млн солдат. Эта цифра считается сегодня самой достоверной [Людские потери СССР]. 
и до конца 1990-х гг. нарастающий вал международной научной литературы дал повод многочисленным публичным дискуссиям ${ }^{13}$.

Сознательное замалчивание, фальсификация и приукрашивание военной правды знакомы нам также и по немецкой истории. Вспомним, например, ежегодное празднование дня Седана 2 сентября в Германской империи по поводу победы над Францией в 1870 г., которое должно было способствовать сплочению народа вокруг идеи его героической силы и превосходства. В первой половине 50-х гг. ХХ столетия бывшие немецкие генералы (Ф. Гальдер, Г. Гудериан, Э. фон Манштейн и др.) в своих мемуарах представляли явно приукрашенную картину ведения войны и оккупационной политики вермахта на Востоке, что мало соответствовало реальности (см.: [Die Wehrmacht; Rüß, 1998]).

Наряду с США после 1945 г. Советский Союз утвердился в качестве второй мировой сверхдержавы. Победа над «фашистским агрессором» все же имела горький привкус. Триумф позволил отодвинуть на задний план для широких кругов населения то, что во внутренней политике происходило дальнейшее усиление и укрепление репрессивной сталинской системы, и любая критика ее негативных сторон и уродливых проявлений жестоко пресекалась [Weber, 1977] ${ }^{14}$. Такой была первая цена победы для многих советских граждан. Второй стало немыслимо высокое число собственных жертв, даже если павшие красноармейцы могли быть почитаемы как герои, которые погибли за защиту родины и «правое дело». Их имена были увековечены в советских военных мемориалах, которые до сих пор располагаются в том числе и на территории бывшей ГДР. Но несомненный трагизм положения заключается в том, что красноармейцы отождествлялись с политической системой, за которую они сражались и которая у подавляющего большинства немцев вызывала осуждение. Тем самым освободительное дело советских солдат и принесенные ими жертвы не находили того признания со стороны побежденных, которого они заслужили ${ }^{15}$. Подобный трагизм амбивалентной культуры воспоминания о победоносных советских солдатах находит свое отражение

${ }^{13}$ Рабочая группа Института военной истории в Москве в 1993 г. заявила о необходимости составить новую историю Великой Отечественной войны, поскольку в прежние годы «тенденциозная и односторонняя подгонка многих публикаций» в соответствии с указаниями партии приводила «нередко к искаженному изложению военного прошлого» [Müller, Ueberschär, S. 10].

${ }_{14}$ Автор утверждает, что «методы насилия, прежде всего террора, пожалуй, вряд ли были исторической необходимостью, а скорее служили интересам (иногда только мнимым) господствующего аппарата или власти Иосифа Сталина» [Weber, 1977, S. 17]. Подобная тенденция присутствует и в новой книге Й. Баберовского [Baberowski, 2012]. В его же книге 2003 г. он объяснял деспотизм Сталина еще как «модернизирующий террор» [Baberowski, 2003]. В новой, уже отмеченной призами книге Сталин характеризуется как заядлый насильник и психопат, который утопил в крови мечту о новом человеке и был зачинщиком и режиссером террора. Большевистский проект как бы предоставлял оправдания для массовых убийств, но не предписывал их.

15 Поэтому надо приветствовать то, что многочисленные памятники павшим советским солдатам на территории бывшей ГДР и советским военнопленным, например, на территории бывшего лагеря военнопленных № 326 в Штукенброк-Зенне под Билефельдом остаются под присмотром с немецкой стороны, и тем самым к ним сохраняется уважение. 
также в болезненном для многих современных русских восприятии 9 мая другими народами Центральной и Средневосточной Европы, которые часто истолковывают этот день или как начало навязанной им политической системы, как новую «политическую оккупацию», или связывают его с полной утратой их государственной независимости.

Никакими справедливыми или высшими моральными целями невозможно оправдать жертвы войны. Смерть этих людей была настолько же бессмысленна, насколько бессмысленны и аморальны были завоевания и военные цели Гитлера. Однако бесконечное горе, которое оставила после себя война, было и здесь, и там одинаково. Это сближает побежденных и победителей. И остается надеяться, что они и в будущем останутся объединены, в частности, и в том, что чешский философ Эразим Кохак (род. в 1933 г.) сформулировал следующим образом: «Отличие гуманной и цивилизованной нации от варварской состоит не в ее невиновности, а в том, как она обращается с темными сторонами и проблематичными аспектами своей истории» (op. cit.: [Glotz, S. 14]).

\section{Список литературы}

Вайцзеккер, Р. фон. Речь, произнесенная 8 мая 1985 г. по случаю сорокалетия окончания Второй мировой войны. URL: www.bundespräsident.de (дата обращения: 31.05.2017).

Людские потери СССР в Великой Отечественной войне : сб. ст. СПб. : [Б. и.], $1995.190 \mathrm{c}$.

Baberowski J. Verbrannte Erde : Stalins Herrschaft der Gewalt. München : Verlag C. H. Beck, 2012. $606 \mathrm{~S}$.

Baberowski J. Der Rote Terror : Die Geschichte des Stalinismus. München : DVA, 2003. 288 S.

Bischof August Graf von Galen : Akten, Briefe und Predigten 1933-1946 / Hrg. von P. Löffler. Mainz : Matthias-Grünewald-Verlag, 1988. Bd. 2. 1939-1946. S. 699-1417.

Bode $S$. Die vergessene Generation : Die Kriegskinder brechen ihr Schweigen. Stuttgart : Piper Verlag GmbH, 2004. $303 \mathrm{~S}$.

Bonwetsch B. Der «Große Vaterländische Krieg» und seine Geschichte // Die Umwertung der sowjetischen Geschichte / Hrg. von D. Geyer. Göttingen : Vandenhoeck \& Ruprecht, 1991. S. 167-187.

Die Wehrmacht : Mythos und Realität / Hrsg. von R.-D. Müller, H.-E. Volkmann. München : Oldenburg, 1999. $1318 \mathrm{~S}$.

Echternkamp J. Nach dem Krieg : Alltagsnot, Neuorientierung und die Last der Vergangenheit 1945-1949. Zürich : Pendo Verlag, 2003. $288 \mathrm{~S}$.

Einige Familiengeschichten : Erinnerungen-Berichte-Aufsätze / Hrg. von E. Habel. Medebach : [S. n.], 2011.

Fischer A. Handlungsspielräume der UdSSR in der Entstehung des Ost-West-Gegensatzes 1945 bis 1950 // Aus Politik und Zeitgeschichte. 1983. B. 25. S. 13-18.

Gebhardt $M$. Als die Soldaten kamen : Vergewaltigungen deutscher Frauen am Ende des Zweiten Weltkriegs. München : DVA, 2015. 352 S.

Geyer D. Von der Kriegskoalition zum Kalten Krieg / Osteuropa-Handbuch «Sowjetunion» : Außenpolitik I: 1917-1955. Köln ; Wien : [S. n.], 1972. S. 343-381.

Glaser H. Kultur der Trümmerzeit. Einige Entwicklungslinien 1945-1948 // Aus Politik und Zeitgeschichte. 1985. B. 40-41. S. 3-31.

Glotz P. Die Vertreibung : Böhmen als Lehrstück. München : Ullstein, 2003. 272 S.

Götz A. Hitlers Volksstaat : Raub, Rassenkrieg und nationaler Sozialismus. Frankfurt a/M : S. Fischer, 2005. $445 \mathrm{~S}$.

Heer H., Naumann K. Vernichtungskrieg : Verbrechen der Wehrmacht 1941 bis 1944. Hamburg : Hamburger Ed., 1995. 703 S.

Herbert U. Geschichte Deutschlands im 20. Jahrhundert. München : Verlag C. H. Beck, 2014. $1451 \mathrm{~S}$. 
Jacobsen H.-A. Zur Lage der Nation : Deutschland im Mai 1945 // Aus Politik und Zeitgeschichte. 1985. B. 13. S. 1-22.

Jäger M. Literatur und Kulturpolitik in der Entstehungsphase der DDR (1945-1952) //

Aus Politik und Zeitgeschichte. 1985. B. 40-41. S. 34.

Jäger $W$. Die Bundespräsidenten : Von Theodor Heuss bis Richard von Weizsäcker //

Aus Politik und Zeitgeschichte. 1989. B. 16-17. S. 33-47.

Jaspers K. Die Schuldfrage. Zürich : Lambert Schneider, 1946. 106 S.

Kleßmann Ch. Die doppelte Staatsgründung : Deutsche Geschichte 1945-1955. Göttingen : [S. n.], 1982. $605 \mathrm{~S}$.

Kocka J. 1945: Neubeginn oder Restauration? // Wendepunkte deutscher Geschichte 1848-1990 / Hrg. von C. Stern und H. A. Winkler. Frankfurt a/M : Fischer, 1994. S. 141-168. Kocka J. Ursachen des Nationalsozialismus // Aus Politik und Zeitgeschichte. 1980. B. 25. S. 3-15.

Krauss $M$. Heimkehr in ein fremdes Land : Geschichte der Remigration nach 1945. München : Verlag C. H. Beck, 2001. 196 S.

Kronenberg $V$. Patriotismus in Deutschland : Perspektiven für eine weltoffene Nation. Wiesbaden : VS Verlag, 2006. 418 S.

Merrit A., Merrit R. Public Opinion in Occupied Germany : The OMGUS Surveys 1945-1949. Urbana : Univ. of Illinois Press, 1970. 364 S.

Mironenko S., Niethammer L., von Plato A. Sowjetische Speziallager in Deutschland

1945-1950. Berlin : Akademie-Verlag, 1998. Bd. 1. 472 S. Bd. 2. 255 S. Müller R.-D., Ueberschär G. R. Hitlers Krieg im Osten 1941-1945 : Ein Forschungsbericht. Darmstadt: WBG, 2000. $452 \mathrm{~S}$.

Redmer K. 1945 - die letzte Kampfhandlung in Mecklenburg // Mecklenburg Magazin. 1997. № 9. S.11.

Rückkehr und Aufbau nach 1945 : Deutsche Remigranten im öffentlichen Leben Nachkriegsdeutschlands / Hrg. von C.-D. Krohn, P. zur Mühlen. Marburg : [S. n.], 1997. 360 S. Rüß H. Familiengeschichte und Russlandinteresse // Quaestio Rossica. 2013. № 1. S. 20-26. Rüß H. Wer war verantwortlich für das Massaker von Babij Jar? // Militärgeschichtliche Mitteilungen. 1998. Bd. 57. S. 483-508. Schelsky H. Die skeptische Generation : Eine Soziologie der deutschen Jugend. Düsseldorf; Köln : [S. n.], 1963. 409 S. Streit Ch. Keine Kameraden : Die Wehrmacht und die sowjetischen Kriegsgefangenen 1941-1945. Bonn : Verlag J. H. W. Dietz Nachf., 1991. 448 S. Trittel G. J. Die westlichen Besatzungsmächte und der Kampf gegen den Mangel 1945 1949 // Aus Politik und Zeitgeschichte. 1986. B. 22. S. 20, 28.

Weber H. Die deutschen Kommunisten in der SBZ : Probleme bei der Kaderbildung vor der SED-Gründung // Aus Politik und Zeitgeschichte. 1978. B. 31. S. 24-31.

Weber H. Stalinismus // Aus Politik und Zeitgeschichte. 1977. B. 4. S. 5-17.

Westerhoft N. Die Mär vom guten Patrioten // Süddeutsche Zeitung. 2007. № 160.

\section{References}

Baberowski, J. (2003). Der Rote Terror : Die Geschichte des Stalinismus. 288 S. München, DVA. Baberowski, J. (2012). Verbrannte Erde : Stalins Herrschaft der Gewalt. 606 S. München, Verlag C. H. Beck.

Bode, S. (2004). Die vergessene Generation : Die Kriegskinder brechen ihr Schweigen. 303 S. Stuttgart, Piper Verlag GmbH.

Bonwetsch, B. (1991). Der «Große Vaterländische Krieg» und seine Geschichte. In D. Geyer (Ed.). Die Umwertung der sowjetischen Geschichte. Göttingen, Vandenhoeck \& Ruprecht. S. 167-187.

Echternkamp, J. (2003). Nach dem Krieg : Alltagsnot, Neuorientierung und die Last der Vergangenheit 1945-1949. 288 S. Zürich, Pendo Verlag.

Fischer, A. (1983). Handlungsspielräume der UdSSR in der Entstehung des Ost-West-Gegensatzes 1945 bis 1950. In Aus Politik und Zeitgeschichte. B. 25. S. 13-18. Gebhardt, M. (2015). Als die Soldaten kamen: Vergewaltigungen deutscher Frauen am Ende des Zweiten Weltkriegs. 352 S. München, DVA.

Geyer, D. (1972). Von der Kriegskoalition zum Kalten Krieg. In W. Markert (Ed.) Osteuropa-Handbuch «Sowjetunion» : Außenpolitik I: 1917-1955. Köln, Wien, [S. n.]. S. 343-381. Glaser, H. (1985). Kultur der Trümmerzeit. Einige Entwicklungslinien 1945-1948. In Aus Politik und Zeitgeschichte. B. 40-41. S. 3-31.

Glotz, P. (2003). Die Vertreibung : Böhmen als Lehrstück. 272 S. München, Ullstein.

Götz, A. (2005). Hitlers Volksstaat : Raub, Rassenkrieg und nationaler Sozialismus. 445 S. Frankfurt a/M, S. Fischer. 
Habel, E. (Ed.). (2011). Einige Familiengeschichten : Erinnerungen-Berichte-Aufsätze. Medebach, [S. n.].

Heer, H., Naumann, K. (1995). Vernichtungskrieg : Verbrechen der Wehrmacht 1941 bis 1944. 703 S. Hamburg, Hamburger Ed.

Herbert, U. (2014). Geschichte Deutschlands im 20. Jahrhundert. 1451 S. München, Verlag C. H. Beck.

Jacobsen, H.-A. (1985). Zur Lage der Nation : Deutschland im Mai 1945. In Aus Politik und Zeitgeschichte. B. 13. S. 1-22.

Jäger, M. (1985). Literatur und Kulturpolitik in der Entstehungsphase der DDR (19451952). In Aus Politik und Zeitgeschichte. B. 40-41. S. 34.

Jäger, W. (1989). Die Bundespräsidenten : Von Theodor Heuss bis Richard von Weizsäcker In Aus Politik und Zeitgeschichte. B. 16-17. S. 33-47.

Jaspers, K. (1946). Die Schuldfrage. 106 S. Zürich, Lambert Schneider.

Kleßmann, Ch. (1982). Die doppelte Staatsgründung : Deutsche Geschichte 19451955. 605 S. Göttingen, Vandenhoek \& Ruprecht.

Kocka, J. (1980). Ursachen des Nationalsozialismus In Aus Politik und Zeitgeschichte. B. 25. S. $3-15$.

Kocka, J. (1994). 1945: Neubeginn oder Restauration? In Stern, C. und Winkler, H. A. (Ed.). Wendepunkte deutscher Geschichte 1848-1990. Frankfurt a/M, Fischer. S. 141-168.

Krauss, M. (2001). Heimkehr in ein fremdes Land: Geschichte der Remigration nach 1945. 196 S. München, Verlag C. H. Beck.

Krohn C.-D. von, Mühlen P. zur (Ed.). (1997). Rückkehr und Aufbau nach 1945 : Deutsche Remigranten im öffentlichen Leben Nachkriegsdeutschlands. 360 S. Marburg, Metropolis.

Kronenberg, V. (2006). Patriotismus in Deutschland: Perspektiven für eine weltoffene Nation. 418 S. Wiesbaden, VS Verlag.

Löffler, P. (Ed.) (1988). Bischof August Graf von Galen : Akten, Briefe und Predigten 1933-1946. Mainz, Matthias-Grünewald-Verlag. Bd. 2. 1939-1946. S. 699-1417.

Lyudskie poteri SSSR v Velikoi Otechestvennoi voine : sbornik statey [Great Patriotic War Casualties of the USSR : Coll. of Articles]. (1995). 190 p. St Petersburg.

Merrit, A., Merrit, R. (1970). Public Opinion in Occupied Germany : The OMGUS Surveys 1945-1949. 364 p. Urbana, Univ. of Illinois Press.

Mironenko, S., Niethammer, L., von Plato, A. (1998). Sowjetische Speziallager in Deutschland 1945-1950. 255 S. Berlin, Akademie-Verlag. Bd. 1. 472 S. Bd. 2.

Müller, R.-D., Ueberschär, G. R. (2000). Hitlers Krieg im Osten 1941-1945 : Ein Forschungsbericht. 452 S. Darmstadt, WBG.

Müller, R.-D., Volkmann, H.-E. (Ed.). (1999). Die Wehrmacht : Mythos und Realität. 1318 S. München, Oldenburg.

Redmer, K. (1997). 1945 - die letzte Kampfhandlung in Mecklenburg. In Mecklenburg Magazin. Iss. 9, S. 11.

Rüß, H. (1998). Wer war verantwortlich für das Massaker von Babij Jar? In Militärgeschichtliche Mitteilungen. Bd. 57, S. 483-508.

Rüß, H. (2013). Familiengeschichte und Russlandinteresse. In Quaestio Rossica. Iss. 1, S. 20-26.

Schelsky, H. (1963). Die skeptische Generation : Eine Soziologie der deutschen Jugend. 409 S. Düsseldorf; Köln, Eugen Diederichs Verlag.

Streit, Ch. (1991). Keine Kameraden : Die Wehrmacht und die sowjetischen Kriegsgefangenen 1941-1945. 448 S. Bonn, Verlag J. H. W. Dietz Nachf.

Trittel, G. J. (1986). Die westlichen Besatzungsmächte und der Kampf gegen den Mangel 1945-1949. In Aus Politik und Zeitgeschichte. B. 22. S. 20, 28.

Weber, H. (1977). Stalinismus. In Aus Politik und Zeitgeschichte. B. 4. S. 5-17.

Weber, H. (1978). Die deutschen Kommunisten in der SBZ : Probleme bei der Kaderbildung vor der SED-Gründung . In Aus Politik und Zeitgeschichte. B. 31. S. 24-31.

Weizsäcker, R. von. Rech', proiznesennaya 8 maya 1985 g. po sluchayu sorokaletiya okonchaniya Vtoroi mirovoi voiny [Speech Delivered on May 81985 on the $40^{\text {th }}$ Anniversary of the End of World War II]. URL: www.bundespräsident.de (mode of access: 31.05.2017).

Westerhoff, N. (2007). Die Mär vom guten Patrioten. In Süddeutsche Zeitung. № 160. URL: http://www.sueddeutsche.de/wissen/liebe-zum-land-die-maer-vom-guten-patrioten-1.912131 (mode of access: 31.05 .2017 ).

Translation by Anna Burova (Versmold, FRG), Nikolaj Baranov (Ekaterinburg) The article was submitted on 14.04.2016 